\title{
GAMBARAN PENGETAHUAN IBU HAMIL TENTANG MANFAAT ASAM FOLAT DALAM KEHAMILAN DI RUMAH SAKIT HAJI MEDAN
}

\author{
Rini Andarwati \\ Jurusan Farmasi Poltekkes Kemenkes Medan
}

\begin{abstract}
Abstrak
Asam folat (vitamin B9) sangat penting selama kehamilan, dan merupakan satu-satunya vitamin yang kebutuhannya selama hamil berlipat dua.Pemberian asam folat pada ibu hamil diketahui untuk mencegah terjadinya neural tube defect (cacat tabung saraf), terutama spina bifida (tulang belakang tidak menutup sempurna) dan anencepali (otak janin tidak terbentuk). Tujuan dari penelitian ini adalah untuk mengetahui gambaran pengetahuan ibu hamil tentang manfaat asam folat dalam kehamilan di Rumah Sakit Haji Medan. Metode penelitian yang digunakan adalah survei deskriptif. Populasi yang digunakan adalah ibu - ibu hamil yang berkunjung ke Poliklinik Ibu Hamil RS Haji Medan dan diambil sampel sebanyak 74 orang. Sampel diambil dengan menggunakan metode Nonprobabillty Sampling dengan jenis sampel jenuh dimana semua anggota populasi menjadi sampel. .Penelitian ini menggunakan instrumen berupa kuesioner. Dari hasil penelitian didapat bahwa responden dengan pengetahuan baik memiliki persentase yang baik yaitu 55.40\%, pengetahuan cukup $35.14 \%$ dan pengetahuan kurang $9.46 \%$. Kesimpulan dari penelitian tersebut didapat bahwa dalam hal pengetahuan ibu hamil tentang manfaat asam folat dalam kehamilan termaksud dalam kategori baik. Saran yang bisa diberikan adalah lebih ditingkatkan lagi program penyuluhan gizi bagi ibu hamil dan perlunya keterlibatan keluarga (suami, orangtua ataupun mertua) dalam menjaga nutrisi ibu hamil.
\end{abstract}

Kata kunci : Pengetahuan, asam folat, ibu hamil

\section{PENDAHULUAN}

Ibu dan janin memiliki kebutuhan gizi yang berbeda disetiap tahap kehamilan. Idealnya, ibu harus berada dalam kondisi prima sebelum hamil sehingga mulai dari pembuahan, janin ibu memiliki kesempatan tumbuh yang terbaik. Pola makan yang baik selama kehamilan menentukan perkembangan janin yang optimal (Zita, 2010).

Asam folat (vitamin B9) sangat penting selama kehamilan, dan merupakan satu-satunya vitamin yang kebutuhannya selama hamil berlipat dua. Sekitar 24-60\% wanita, baik di negara sedang berkembang maupun yang telah maju mengalami kekurangan asam folat karena kandungan asam folat didalam makanan sehari-hari mereka tidak cukup untuk memenuhi kebutuhan wanita hamil. Angka kecukupan sehari asam folat bagi ibu hamil

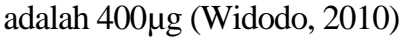

Kekurangan asam folat berkaitan dengan berat lahir rendah, ablasio plasenta (lepasnya plasenta sebelum waktunya),dan neural tube defect (cacat tabung saraf). Pemberian suplementasi terbukti mampu menghapus kelainan ini.. Wanita yang mengkonsumsi tambahan asam folat 2-4 bulan sebelum dan di awal kehamilan dapat mengurangi kelahiran bayi dengan cacat pada otak (Aliyah, 2009)

Berdasarkan uraian latar belakang masalah diatas dapat diketahui bahwa peningkatan prevalensi terjadinya neural tube defect dapat dicegah dengan cara memberikan suplementasi asam folat pada saat kehamilan, maka perlu dilakukan penelitian bagaimana gambaran pengetahuan ibu hamil tentang manfaat asam folat dalam kehamilan di Rumah Sakit Haji Medan.

Tujuan dari penelitian ini adalah untuk mengetahui gambaran pengetahuan ibu hamil tentang manfaat asam folat dalam kehamilan di Rumah Sakit Haji Medan. Sampel diambil dengan menggunakan metode Nonprobability Sampling dengan jenis sampel sampling jenuh,yaitu dengan mengambil semua anggota populasi menjadi sampel. Variabel bebas adalah umur, pekerjaan dan pendidikan sedangkan variabel terikat tingkat pengetahuan baik, cukup dan kurang Penelitian ini bersifat survei deskriptif untuk memperoleh data dan mengetahui gambaran pengetahuan ibu hamil tentang manfaat asam folat pada masa kehamilan di Rumah Sakit Haji Medan. Data yang digunakan adalah data primer. yang diperoleh langsung dari responden melalui pengisian kuesioner dan data sekunder dari Rumah Sakit Haji Medan. Analisi data dengan melihat persentase data terkumpul dan disajikan dalam bentuk tabel distribusi frekuensi. Pengetahuan diukur melalui jawaban kuesioner, 20 pertanyaan yang dibuat berdasarkan tingkatan pengetahuan didalam domain kognitif dengan skor 3 (a), 2 (b) dan 1 (c). Skor tertinggi dari pengatahuan adalah 60 dan skor terendah adalah 20. Berdasarkan 
total skor yang diperoleh responden, pengetahuan dibagi menjadi tiga tingkat, yaitu : pengetahuan baik= skor $>44(>75 \%)$, pengetahuan cukup = skor 30-44 $(50 \%-75 \%)$ dan pengetahuan kurang $=$ skor $<30$ $(<50 \%)$.

\section{Hasil Penelitian \\ Deskripsi Karakteristik Responden}

Dari hasil penelitian yang telah dilakukan di Rumah Sakit Haji Medan, diperoleh data-data yang dikumpulkan dan disajikan dalam bentuk tabel seperti yang diuraikan dibawah ini

Tabel 1. Distribusi Karakteristik Responden

\begin{tabular}{|c|c|c|c|}
\hline $\mathrm{NO}$ & Data & Frekuensi & $\begin{array}{c}\text { Persentase } \\
(\%)\end{array}$ \\
\hline \multirow[t]{3}{*}{1} & UMUR & & \\
\hline & a. $21-30$ tahun & 46 & \\
\hline & b. $31-40$ tahun & 28 & \\
\hline \multirow[t]{4}{*}{2} & PENDIDIKAN & & \\
\hline & a. SD - SMA & 50 & \\
\hline & b. $<$ Pendidikan & 24 & \\
\hline & $\begin{array}{l}\text { tinggi } \\
\text { Akademi, } \\
\text { Sarjana }\end{array}$ & & \\
\hline \multirow[t]{4}{*}{3} & PEKERJAAN & & \\
\hline & a. Pegawai Negeri & 19 & 25.68 \\
\hline & b. Pegawai swasta & 17 & 22.97 \\
\hline & $\begin{array}{l}\text { d. IRT (Ibu rumah } \\
\text { tangga) }\end{array}$ & 38 & 51.35 \\
\hline
\end{tabular}

Berdasarkan tabel 1 dapat terlihat bahwa dari 74 responden yang paling banyak berusia 26-30 tahun yaitu sebanyal 32 orang (43.24\%), dan responden yang paling banyak berpendidikan menengah (SMA / Sederajat) yaitu sebanyak 39 orang ( $52.70 \%$ ) dan pekerjaan responden sebagian besar adalah IRT yaitu sebanyak 38 orang $(51.35 \%)$.

3.9.2 Deskripsi Pengetahuan Responden

Table 2 Distribusi Pengetahuan Responden Terhadap Manfaat Asam

\begin{tabular}{ccc}
\hline Pendidikan & Frekuensi & Persentase $(\%)$ \\
\hline Baik & 41 & 55.40 \\
Cukup & 26 & 35.14 \\
Kurang & 7 & 9.46 \\
\hline TOTAL & 74 & 100 \\
\hline
\end{tabular}

Berdasarkan tabel 2 dapat dilihat bahwa responden yang memiliki pengetahuan baik memiliki persentase yang paling tinggi yaitu $55.40 \%$ (41 orang), pengetahuan cukup baik 35.14\% (26 orang) dan pengetahuan kurang baik adalah $9.46 \%$ (7 orang).
Tabel 3 Tabulasi Silang Antara Umur dengan Pengetahuan

\begin{tabular}{|c|c|c|c|c|c|c|c|}
\hline \multirow{2}{*}{$\begin{array}{c}\text { Umur } \\
\text { (Tahun) }\end{array}$} & \multicolumn{6}{|c|}{ Interprestasi Pengetahuan } & \multirow{2}{*}{ Tota } \\
\hline & Baik & $\%$ & Cukup & $\%$ & Kurang & $\%$ & \\
\hline $21-25$ & 7 & 50 & 5 & 35.71 & 2 & 14.29 & 14 \\
\hline $26-30$ & 21 & 65.62 & 10 & 31.25 & 1 & 3.13 & 32 \\
\hline $31-35$ & 10 & 55.56 & 6 & 33.34 & 2 & 11.12 & 18 \\
\hline $36-40$ & 3 & 30 & 5 & 50 & 2 & 20 & 10 \\
\hline
\end{tabular}

Berdasarkan tabel 3 dapat dilihat bahwa responden yang memiliki pengetahuan baik dengan persentasi tertinggi adalah pada usia 26-30 tahun yaitu sebesar $65.62 \%$, sedangkan yang berpengetahuan baik dengan persentase terendah adalah pada usia 36-40 tahun yaitu sebesar $30 \%$.

Tabel 4 Tabulasi Silang Antara Pendidikan dengan Pengetahuan

\begin{tabular}{|c|c|c|c|c|c|c|c|}
\hline \multirow{2}{*}{ Pendidikan } & \multicolumn{6}{|c|}{ Interprestasi Pengetahuan } & \multirow{2}{*}{ Total } \\
\hline & Baik & $\%$ & Cukup & $\%$ & Kurang & $\%$ & \\
\hline Dasar & 2 & 18.18 & 4 & 36.37 & 5 & 45.45 & 11 \\
\hline Menengah & 18 & 46.15 & 19 & 48.72 & 2 & 5.13 & 39 \\
\hline Tinggi & 21 & 87.5 & 3 & 12.5 & - & & 24 \\
\hline
\end{tabular}

Berdasarkan tabel 4 dapat dilihat bahwa responden yang memiliki pengetahuan baik dengan persentasi tertinggi adalah pada pendidikan tinggi yaitu sebesar $87.5 \%$, sedangkan yang berpengetahuan baik dengan persentase terendah adalah pada pendidikan dasar yaitu sebesar $18.18 \%$.

Tabel 5 Tabulasi Silang Antara Pekerjaan dengan Pengetahuan

\begin{tabular}{cccccccc}
\hline \multirow{2}{*}{ Pekerjaan } & \multicolumn{7}{c}{ Interprestasi Pengetahuan } \\
\cline { 2 - 7 } & Baik & $\%$ & Cukup & $\%$ & Kurang & $\%$ & \\
\hline Pegawai Negeri & 15 & 78.95 & 4 & 21.05 & - & - & 19 \\
Pegawai swasta & 9 & 52.94 & 7 & 41.18 & 1 & 5.88 & 17 \\
IRT (Ibu rumah & 17 & 44.74 & 15 & 39.47 & 6 & 15.79 & 38 \\
tangga) & & & & & & & \\
\hline
\end{tabular}

Berdasarkan tabel 5 dapat dilihat bahwa responden yang memiliki pengetahuan baik dengan persentasi tertinggi adalah yang berprofesi sebagai pegawai negri yaitu sebesar $78.95 \%$, sedangkan yang berpengetahuan baik dengan persentase terendah adalah yang berprofesi sebagai IRT (Ibu Rumah Tangga) yaitu sebesar $44.74 \%$.

\section{PEMBAHASAN}

\section{Pengetahuan Ibu Hamil Terntang Manfaat Asam Folat Dalam Kehamilan}

Berdasarkan tabel 2 deskripsi pengetahuan responden, diketahui bahwa tingkat pengetahuan ibu hamil tentang manfaat asam folat dalam kehamilan sebagian besar dalam kategori baik dengan persentase sebesar $55.40 \%$ (41 orang), sisanya tergolong dalam kategori pengetahuan cukup sebesar 35.14\% (26 orang) dan pengetahuan kurang sebesar $9.46 \%$ (7 orang). Pengetahuan diperoleh setelah orang melakukan pengindraan terhadap suatu objek tertentu. Penginderaan terjadi melalui panca indera manusia yaitu indera penglihatan, pendengaran, penciuman, rasa dan raba. 
Sebagian besar pengetahuan manusia diperoleh melalui mata dan telinga (Notoatmodjo, 2003). Tingkat pengetahuan yang baik pada responden mungkin dipengaruhi latar belakang responden yang banyak menerima informasi-informasitentang asupan asam folat pada masa kehamilan, sehingga memiliki pemahaman yang baik untuk menjawab kuesioner penelitian dengan benar.

\section{Tabulasi Silang Antara Umur Responden dengan Pengetahuan}

Berdasarkan tabel 3 tabulasi silang antara umur responden dengan pengetahuan dapat dilihat bahwa responden yang memiliki pengetahuan baik dengan persentasi tertinggi adalah pada usia 26-30 tahun yaitu sebesar 65.62\%, sedangkan yang berpengetahuan baik dengan persentase terendah adalah pada usia 36-40 tahun yaitu sebesar 30\%.

Usia mempengaruhi terhadap daya tangkap dan pola pikir seseorang. Semakin bertambah usia akan semakin berkembang pula daya tangkap dan pola pikirnya, sehingga pengetahuan yang diperolehnya semakin membaik. Pada usia yang matang secara fisik dan mental (26-30), individu akan lebih berperan aktif dalam masyarakat dan kehidupan sosial serta lebih banyak melakukan persiapan demi suksesnya upaya menyesuaikan diri menuju usia tua, selain itu orang pada usia ini akan lebih banyak menggunakan banyak waktu untuk membaca. Kemampuan intelektual, pemecahan masalah, dan kemampuan verbal dilaporkan hampir tidak ada penurunan pada usia ini (Widayatun, 1999).

Peneliti menduga adanya kaitan antara umur dengan perilaku ibu hamil, pada usia yang cukup matang secara fisik dan mental(25-26) tentunya pengetahuan dan pola fikir ibu hamil akan lebih baik dibandingkan dengan usia ibu hamil yang cukup tua (36-40). Semakin tua usia seseorang (36-40) maka semakin sulit baginya untuk menerima pengetahuan-pengetahuan baru. Dapat diperkirakan bahwa IQ akan menurun sejalan dengan bertambahnya usia, khususnya pada beberapa kemampuan yang lain seperti misalnya kosa kata dan pengetahuan umum (Widayatun, 1999).

Beberapa teori berpendapat ternyata IQ seseorang akan menurun cukup cepat sejalan dengan bertambahnya usia.

\section{Tabulasi Silang Antara Pendidikan Responden dengan Pengetahuan}

Berdasarkan tabel 4 tabulasi silang antara pendidikan responden dengan pengetahuan dapat dilihat bahwa responden yang memiliki pengetahuan baik dengan persentasi tertinggi adalah pada pendidikan tinggi yaitu sebesar $87.5 \%$, sedangkan yang berpengetahuan baik dengan persentase terendah adalah pada pendidikan dasar yaitu sebesar $18.18 \%$.

Pendidikan adalah suatu usaha untuk mengembangkan kepribadian dan kemampuan di dalam dan di luar sekolah dan berlangsung seumur hidup. Pendidikan mempengaruhi proses belajar, makin tinggi pendidikan seeorang makin mudah orang tersebut untuk menerima informasi. Dengan pendidikan tinggi maka seseorang akan cenderung untuk mendapatkan informasi, baik dari orang lain maupun dari media massa. Semakin banyak informasi yang masuk semakin banyak pula pengetahuan yang didapat tentang kesehatan. Pengetahuan sangat erat kaitannya dengan pendidikan dimana diharapkan seseorang dengan pendidikan tinggi, maka orang tersebut akan semakin luas pula pengetahuannya (Widayatun, 1999).

Peneliti juga menduga adanya kaitan antara pendidikan dengan pengetahuan ibu hamil. Dengan tingginya tingkat pendidikan seseorang tentunya pengetahuan dan kesadaran seseorang akan tinggi juga.

\section{Tabulasi Silang Antara Pekerjaan Responden dengan Pengetahuan}

Berdasarkan tabel 5 dapat dilihat bahwa responden yang memiliki pengetahuan baik dengan persentasi tertinggi adalah yang berprofesi sebagai pegawai negri yaitu sebesar $78.95 \%$, sedangkan yang berpengetahuan baik dengan persentase terendah adalah yang berprofesi sebagai IRT (Ibu Rumah Tangga) yaitu sebesar $44.74 \%$.

Pekerjaan adalah pencaharian yang dijadikan pokok penghidupan atau sesuatu yang dilakukan untuk mendapatkan nafkah. Pekerjaan berhubungan erat dengan interaksi dengan orang lain. Jenis pekerjaan yang menuntut seseorang berinteraksi secara intens dengan orang mempunyai kemungkinan adanya pertukaran pengetahuan. Sebagaimana dikemukakan oleh Notoatmodjo (2003) yang mengatakan bahwa sumber informasi dapat berasal dari rekan kerja.

Peneliti menduga adanya kaitan antara pekerjaan dengan pengetahuan ibu hamil, responden yang berprofesi sebagai ibu rumah tangga pengetahuannya akan lebih sedikit jika dibandingkan dengan responden yang berprofesi sebagai PNS. Oleh karena dengan adanya interaksi dan komunikasi serta pertukaran pengetahuan dengan teman-teman rekan kerjanya maka Ibu yang berprofesi sebagai PNS pengetahuaannya akan lebih luas.

\section{KESIMPULAN DAN SARAN}

\section{Kesimpulan}

Dari hasil penelitian dan uraian dari pembahasan diatas dapat ditarik kesimpulan:

Pengetahuan ibu hamil tentang manfaat asam folat dalam kehamilan sebagian besar termaksud dalam kategori baik dengan persentase sebesar $55.40 \%$ (41 orang) sisanya tergolong dalam kategori pengetahuan cukup baik sebesar $35.14 \%$ (26 orang) dan pengetahuan kurang baik sebesar $9.46 \%$ (7 orang).

1. Tabulasi silang antara umur responden dengan pengetahuan. Responden yang memiliki pengetahuan baik dengan persentasi tertinggi adalah pada usia 26-30 tahun yaitu sebesar $65.62 \%$, sedangkan yang berpengetahuan baik 
dengan persentase terendah adalah pada usia 3640 tahun yaitu sebesar $30 \%$.

2. Tabulasi silang antara pendidikan responden dengan pengetahuan. Responden yang memiliki pengetahuan baik dengan persentasi tertinggi adalah pada pendidikan tinggi yaitu sebesar $87.5 \%$, sedangkan yang berpengetahuan baik dengan persentase terendah adalah pada pendidikan dasar yaitu sebesar $18.18 \%$.

3. Tabulasi silang antara pendidikan responden dengan pengetahuan. Responden yang memiliki pengetahuan baik dengan persentasi tertinggi adalah yang berprofesi sebagai pegawai negri yaitu sebesar $78.95 \%$, sedangkan yang berpengetahuan baik dengan persentase terendah adalah yang berprofesi sebagai IRT (Ibu Rumah Tangga) yaitu sebesar $44.74 \%$.

\section{Saran}

Berdasarkan hasil penelitian yang telah dilakukan terdapat beberapa saran dari peneliti diantaranya :

1. Dimasa yang akan datang diharapkan peneliti lain bisa melanjutkan penelitian tentang prilaku ibu hamil tentang manfaat asam folat dalam kehamilan untuk mengetahui sikap dan tindakan dari ibu hamil terhadap pentingnya asam folat pada masa kehamilan.

2. Diharapkan kepada pihak terkait (posyandu dan puskesmas) untuk lebih meningkatkan lagi program penyuluhan gizi bagi ibu hamil khususnya mengenai asam folat. Selain itu dalam hal penyuluhan perlu adanya keterlibatan pihak keluarga (suami, orangtua, dan mertua) karena dalam hal menjaga nutrisi ibu hamil tidak hanya peran ibu hamil itu sendiri melainkan memerlukan peran keluarga maupun masyarakat sekitar

\section{DAFTAR PUSTAKA}

Arisman. (2004). Gizi Dalam Daur Kehidupan , ECG , Jakarta.

Hidayat, A. (2009). Metodologi Penelitian Kebidanan dan Teknik Analisa Data, Salemba Medika, Jakarta.

Notoatmodjo, S. (2003). Pendidikan dan Prilaku Kesehatan, PT. Rineka Cipta, Jakarta.

Notoatmodjo, S. (2010). Metodologi Penelitian Kesehatan , PT. Rineka Cipta, Jakarta.

Sudjana. ( 2005) . Metode Statistika, Tarsito, Bandung.

Suhardjo. (1992). Prinsip-prinsip Ilmu Gizi , Kanisius, Yogyakarta.

Suryani. ( 2002). Gizi Kesehatan Ibu dan Anak, PT. Rineka Cipta, Jakarta.

West, Z. (2010). Natural Pregnancy Panduan Lengkap Menjalani Kehamilan Secara Alamiah, Pustaka Bunda, Jakarta.

Wibisono, H. (2009). Solusi Sehat Seputar Kehamila, Agro Media Pustaka, Jakarta.

www.aliyahbaby.com.htm 